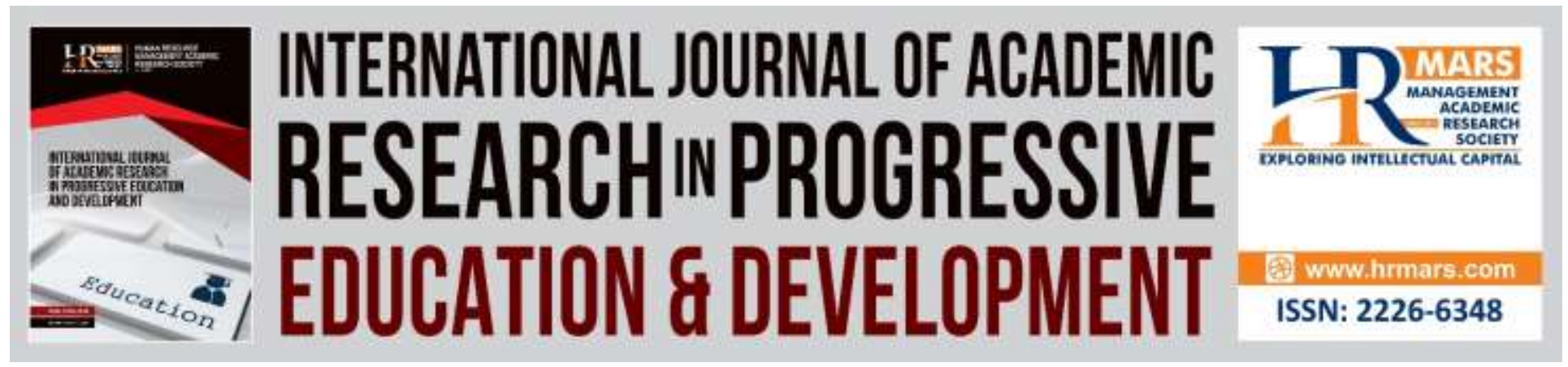

\title{
Practice of Use of Materials to Teach Islamic Education Teachers of Religious High School
}

\section{Muhamad Maamun Abdullah}

To Link this Article: http://dx.doi.org/10.6007/IJARPED/v8-i4/6908

DOI:10.6007/IJARPED/v8-i4/6908

Received: 19 September 2019, Revised: 20 November 2019, Accepted: 11 December 2019

Published Online: 30 December 2019

In-Text Citation: (Abdullah, 2019)

To Cite this Article: Abdullah, M. M. (2019). Practice of Use of Materials to Teach Islamic Education Teachers of Religious High School. International Journal of Academic Research in Progressive Education and Development, 8(4), 1088-1093.

Copyright: (C) 2019 The Author(s)

Published by Human Resource Management Academic Research Society (www.hrmars.com)

This article is published under the Creative Commons Attribution (CC BY 4.0) license. Anyone may reproduce, distribute, translate and create derivative works of this article (for both commercial and non-commercial purposes), subject to full attribution to the original publication and authors. The full terms of this license may be seen at: http://creativecommons.org/licences/by/4.0/legalcode

Vol. 8(4) 2019, Pg. 1088 - 1093

http://hrmars.com/index.php/pages/detail/IJARPED

JOURNAL HOMEPAGE

Full Terms \& Conditions of access and use can be found at http://hrmars.com/index.php/pages/detail/publication-ethics 


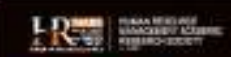 INTERNATIONAL JOURNAL OF ACADEMIC PRESEARCHINPROGRESSIVE EDUCATION \& DEVELOPMENT

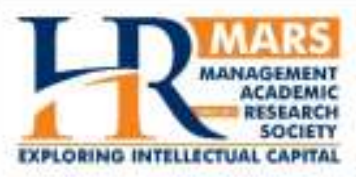 2 \\ Practice of Use of Materials to Teach Islamic Education Teachers of Religious High School
}

\author{
Muhamad Maamun Abdullah \\ Muhammad Razak bin Idris, Malaysia
}

\begin{abstract}
This article is intended to focus a discussion on the use of materials to teach Islamic education teachers in teaching and learning. The general opinion shows that the teaching practices of Islamic education teachers have a close relationship on the effectiveness of education. Therefore, Islamic educational teachers should diversify strategies, methods and techniques during their teaching in class. The use of teaching materials is one way to manage the quality of teaching implementation. There are at least two aids teaching materials that need to be practiced by teachers such as electronic and non-electronic materials so that teaching quality can be improved. As a whole, teachers should be aware that the use of teaching materials can be impacted by attracting interest and enhancing students ' performance and achieving educational objectives in communicating students ' education.
\end{abstract}

\section{Introduction}

Student's excellence is always associated with the relationship of teaching by teachers and student learning methods. Teaching is defined as the delivery process of knowledge, skill, value and attitude. The purpose of learning is to be the process of information ownership, knowledge, skills mastery and habit and creation of attitudes and beliefs. Teachers in context in the classroom are instrumental in implementing quality teaching and learning process to students, this effort in line with the country's aspiration to become developed countries by 2020 . This situation makes teachers urged to implement their responsibility to educate students with the best possible in order to ensure that students can control what is being taught. These include the use of teaching aids during the teaching and learning process in the classroom. Through the use of teaching materials, this can help the Islamic education teachers explain the content of education more accurately and properly compared to oral teaching.

Interesting and up-to-date teaching is among the main factors attracting students ' interest in learning. Interesting teaching techniques cause learners not to get bored of learning. Excellent teaching is capable of giving great influence to the minds and souls of the students and capable of mobilizing students ' interest, achievement and perception of lessons taught (Tamuri 2008). Teaching techniques that are interesting indirectly will spark learning interest to students. 


\section{Teaching Aids}

Teaching aids (BBM) It is a very useful tool for teachers while teaching. Learning using teaching materials (BBM) helps to ensure that students are able to provide effective understanding students and to attract their interest towards the subjects taught. According to Long (1982), teaching materials and teaching aids there are various types of them in the form of books, charts or slides emitted on the screen. Materials that support the present of learning are given the name of teaching aids.

Basically, the teaching aids (BBM) means tools that can help a teacher in the teaching process. This teaching material is not only limited to textbooks, stationery and photographs but includes all things used in education that can be seen, heard, held, read, told, felt, are inhaled, used and so on. Teaching materials are anything experienced by students (Hussin, 1986). According to Hill, Rowan and Ball (2015) studies stating teacher knowledge and skills is more important than teacher preparation to teach. Therefore, the Islamic education teacher has always mastered the skills of the use of teaching materials in order to improve the teaching quality.

Long (1981) divides the teaching aids (ABM) to three groups, which are hearing tools, perspective tools and headsets. Hamid (1981) classifies the tool to two groups, which are electronic media and non-electronic media. While Moses \& Mohamad (2014) pointed out that BBM can be categorized into two types, electronic and non-electronic. Among the BBM such as radio, projector and slide, television, video and computer-assisted equipment are BBM electronic. While magazines, models, scanning cards, journals and photos related to teaching and learning is a non-electronic type of BBM. According to Jasmi et al. (2011), it states that BBM is classified into two types of patterns namely BBM-shaped patterns and BBM-shaped instead of patterns. There are six types of BBM which are textbooks, computers and LCD are the main patterns. Meanwhile, circular paper and modules, reference books, mahjong papers and images are BBM-shaped side patterns. In addition, BBM such as charts, tapes, materials, press and paper, training books, movie and video, radio, audio files, black and white boards, Manila paper Cards, folio and OHP and transparency is a BBM that does not form a pattern.

Atan Long's Opinion (1982) consists of various materials. Something can be conveyed with various ways. For example, a material may be published in book form, in a chart form or placed on slides and transmits to the screen. The its delivery tools are called the Teaching aids (ABM) based on the above opinion, gave to be divided into three stages, namely (Hussin, 1987). The first stage of materials that use electronic media such as lesson movies, slide movies, projectors (overhead), video tapes, radios, recording tapes, record etc. The second level is the ingredients that do not use electronic media such as voice, books, model chart pictures, newspapers, stationery, scanning cards etc. And the third stage are materials that have patterns of experience such as acting, pantomime, tours, exhibition projects and materials from the environment. Thus, when the teacher's decision to use BBM implemented in school into interaction teachers can give students the satisfaction of the study and thus help ensure the successful implementation of a program (Noh et. al., 2013). 
Vol. 8, No. 4, 2019, E-ISSN: 2226-6348@ 2019 HRMARS

\section{The Importance of Teaching Aids}

According to Norzainariah Bt. Abu Hassan in his writings titled Kebolehgunaan Kit Pengajaran dan Pembelajaran bagi Meningkatkan Prestasi Pelajar, stating a survey in Kuittho 2004, explains that the teaching materials can be broken to two non-electronic categories and also non-electronic categories. Teaching materials categorized as electronic such as television, radio, video screenings, slides from projector and computer aided devices. While the materials of teaching are classified as non-electroic, such as magazines, models, journals, photos and even scan cards with respect to lessons taught.

According to Mohsin \& Hassan (2011); Sahid, Noordin, \& Sani, (2018); Ejike, (2018), emphasizing the importance of using BBM in teaching and learning among teachers is to assist teachers in imparting knowledge in the teaching and learning process, saving teachers time and energy in providing BBM, helping teachers respond to challenges by increasing the potential of using the latest technology, positively impacting students in the teaching and learning process, the centrality of teaching and learning resources and, finally, the provision of teachers for the use of BBM in teaching and learning in the 21st century. The use of teaching aids to engage students in learning is as stated by Ahmad \& Jinggan (2015). States that teachers should use appropriate techniques to stimulate student interest in the teaching and learning process. Achievement and success can be improved as Jaafar (2017) argues that using BBM is a way to increase achievement and success for students because without BBM, the teaching and learning process will be less quality and effective and academic achievement will decrease.

\section{Effectiveness of Teaching Aids}

The intended impression will apply a form of addition and edification or change in a better direction in student learning. A change that gives the student meaning to themselves. Therefore, if the impact does not exist, it cannot be cited as the learning process for students.

Therefore, it is necessary to implement a structured and systematic teaching materials that will produce something in teaching as stated as Marzuki (2005) that the enjoyment of students for learning, skill or concept is easy to understand By students and teacher's willingness to convey teaching is the quality of a teaching in school.

It will be something that causes positive changes or progress in education that can encourage students ' interest to obtain good grades in the examination (Nasir \& Hamzah, 2014; Chrysoula, 2014). Finally, the use of teaching materials is capable of providing a more noticeable experience than just the words spoken. Understanding rates can also be enhanced through a variety of exciting and distinct learning experiences.

\section{Conclusion}

The use of teaching materials for an Islamic educational teacher is not only to give information and to describe the content of lessons through textbooks such as familiarity, but need to diversify the help of fun teaching. This helps to teach the teachers to move knowledge to students, as well as to build social interactions between teachers and students during teaching and learning. The quality of teaching can be improved so that the impact of the students will be active in learning and easily mastering and understand the lesson, thus creating success in education. 
INTERNATIONAL JOURNAL OF ACADEMIC RESEARCH IN PROGRESSIVE EDUCATION AND

DEVELOPMENT

Vol. 8, No. 4, 2019, E-ISSN: 2226-6348 @ 2019 HRMARS

\section{Corresponding Author}

Muhamad Maamun Abdullah

Jabatan Usuluddin dan Falsafah

Fakulti Pengajian Islam

Universiti Kebangsaan Malaysia, 43600 UKM Bangi, Selangor, Malaysia

Email: maamunabdullah@yahoo.com

\section{References}

Journal Articles

Anuar, A., \& Jinggan, N. (2015). Pengaruh Kompetensi Kemahiran Guru Dalam Pengajaran Terhadap Pencapaian Akademik Pelajar Dalam Mata Pelajaran Sejarah. Jurnal Kurikulum \& Pengajaran Asia Pasifik. Fakulti Pendidikan. Universiti Kebangsaan Malaysia.

Jasmi, K. A., Ilias, M. F., Tamuri, A. H., \& Hamzah, M. I. (2011). Amalan Penggunaan Bahan Bantu Mengajar Dalam Kalangan Guru Cemerlang Pendidikan Islam Sekolah Menengah Di Malaysia. Journal of Islamic and Arabic Education.

Hill, H.C., Rowan, B., \& Ball, D.L. (2015) Effects of Teachers' Mathematical Knowledge For Teaching On Student Achievement. American Educational Research Journal, 42(2), $371-$ 406.

Sahid, N. Z., Noordin, S. A., \& Sani, M. K. J. A. (2018). Customer-Driven Business Information provision in Malaysian Government Agencies' Library. International Journal of Academic Research in Progressive Education and Development, 7(3), 137-149.

Abdullah, M. M. (2019). Practice of Use of Materials to Teach Islamic Education Teachers of Religious High School. International Journal of Academic Research in Progressive Education and Development, 8(4), 977-982.

CHRYSOULA, P. (2014). Recording Literacy Practices of Monolingual and Bilingual Infants. Multilingual Academic Journal of Education and Social Sciences, 2(2), 86-113.

Ejike, S. I. (2018). An Assessment of Non-Executive Directors Influence on the Operating Profits of Manufacturing Firms in Nigeria, International Journal of Academic Research in Accounting, Finance and Management Sciences 8 (2): 1-8.

\section{Books}

Long, A. (1981). Kaedah am mengajar. Kuala Lumpur: Fajar Bakti Sdn Bhd.

Jaafar, F. B. (2017) Tesis Tajuk Bahan Bantu Mengajar dalam Pengajaran dan Pembelajaran di Sekolah Menengah Daerah Pontian. Universiti Tun Hussein Onn Malaysia.

Marzuki, S. C. (2005). Amalan Guru Yang Berkesan : Kajian Di Beberapa Sekolah Menengah Di Malaysia. Fakulti Pendidikan. Universiti Malaysia.

Musa, N. E., \& Mohamad, M. H. (2014). Keberkesanan Penggunaan Alat Bahan Bantu Mengajar Dalam Pelaksanaan Kursus Sains Kejuruteraan di Kalangan Pelajar Diploma Kejuruteraan Di Politeknik Tuanku Sulatanah Bahiyah. Prosiding PTBS. Politeknik Tuanku Sulatanah Bahiyah.

Mohsin, M. S. F. A., \& Hassan, R. (2011). Pengajaran dan Pembelajaran Berasaskan „Streaming Video" Bagi Meningkatkan Tahap Kefahaman Pelajar Abad Ke21. Universiti Tun Hussein 
INTERNATIONAL JOURNAL OF ACADEMIC RESEARCH IN PROGRESSIVE EDUCATION AND

DEVELOPMENT

Vol. 8, No. 4, 2019, E-ISSN: 2226-6348 C 2019 HRMARS

Oon.

Noh,M. N., Mustafa, A. H. M., Hamzah, M., Ismail, M. A., \& Abdullah, N. (2013). Penggunaan Inovasi Teknologi Dalam Pengajaran : Cabaran Guru Dalam EPembelajaran. Proceedings of The 7th International Malaysian Educational Technology Cinvention (IMETC 2013).

Nasir, M. Z., \& Hamzah, Z. A. Z. (2014). Sikap Motivasi Pelajar Terhadap Pembelajaran Bahasa Melayu. Akademi Bahasa. University Teknologi Malaysia \& Jabatan Bahasa Melayu. Universiti Putra Malaysia.

Hassan, N. B. (2004). "Kebolehgunaan Kit Pengajaran Dan Pembelajaran Bagi Meningkatkan Prestasi Pelajar: Satu Tinjauan Di Kuittho"

Haji. Husin, K. (1986). Penguasaan Bahasa Malaysia di kalangan pelajar bukan Melayu di Maktab Perguruan di Kuala Lumpur. Tesis Master Sains. Fakulti Pengajian Pendidikan. Universiti Pertanian Malaysia.

Stapa, Z., Ismail, A. M., \& Yusuf, N. (2012). Faktor Persekitaran sosial dan Hubungannya Dengan Pembentukan Jati Diri. Fakulti Pengajuan Islam. Universiti Kebangsaan Malaysia. 